the Productus Limestone, and the Talchir shales in the Talchir Boulder Bed" (p. 245 ; also pp. xviii, $\mathrm{xl}, 92)$. Of course, Gee, Sahni and everyone else recognize that the saliferous members of the Saline Series are peculiarly liable to subterranean contamination from without. The only difference of opinion is as to the possibility or impossibility of quasi-universal contamination by introduced dust.

Let it be granted that the dust found everywhere in the Saline Series includes so many examples of recognizable debris of conifers, angiosperms and insects as to be on the whole clearly post-Cambrian.

This second proposition I am prepared to take as a working hypothesis from Sahni and his co-workers. I admit that it involves two separate debatable sub-propositions :

(1) Sahni and his co-workers are certain that the dust particles, which they recognize as remains of conifers, angiosperms and insects, are unmistakable. They publish numerous illustrations, some of them photographs. If botanists and zoologists are withholding criticism out of regard for the authors, they are doing a disservice to science. Gee has asked whether the chitinous dust might not have come from trilobites, rather than insects, and has received an apparently satisfactory answer (pp. 233, 235).

(2) Sahni and co-workers are certain that the particular dust particles, which they identify as bits of conifers, angiosperms and insects, have the same wide distribution as the organic dust as a whole. It might otherwise be suggested that such identifiable material is probably in small proportion and reasonably assignable to contamination. This idea seems to be implicit in Gee's question as to whether the organic remains in the oil-shales might not present a special problem (p. 96), and prove free from post. Cambrian types; but the answer given by Sahni and co-workers is clear, for they maintain that remains of conifers, angiosperms and insects do occur in the oil-shales (pp. ix, xvii, xxii, 53, 187, 204, 205, 207,220 ).

Let it be granted that Gee has demonstrated, on three occasions to first-class audiences in the field, exposures which seem to prove that the Saline Series is 'naturally' overlain by unquestionably Palæozoic formations.

Five of Gee's companions have openly adopted his interpretation. Only Sahni himself has said in print that he has seen and disbelieved. The evidence derives in part from lack of manifest disturbance at the contact, and in part from contained fragments in the base of the Talchir Boulder Bed, where this latter happens to be the lowest member of the overlying succession.

Above are stated the three assumptions which for the time being guide my conclusions. I think Sahni is right in interpreting the organic dust in the Saline Series as wind-borne, and contemporaneous. Accordingly I think that the apparent sub-Cambrian stratigraphical position of the Saline Series is misleading. I realize how seldom a major thrust can escape detection in a non-metamorphic, well-exposed succession ; but I do know one case in Scotland, that of the Kishorn Thrust, a mile south of Broadford, where Torridon Sandstone is brought on to Durness Limestone in such a manner that any one of us might be deceived if he did not know the answer in advance. Let us hope that further research will soon put the Salt Range problem beyond dispute, one way or the other.

Since this review was written, I have read an extremely important letter by A. K. Ghosh and A.
Bose (Nature, December 6, 1947, p. 796), in which the discovery is announced of plant dust of apparent post-Palæozoic type in the Salt Pseudomorph Beds. These beds intervene between the Talchir Boulder Bed, above, and the fossiliferous Cambrian, below, instead of underlying the latter as does the Saline Series so far discussed. The elaboration of this find may well lead to decisive results. At first sight it seems rather to weaken Sahni's position.

In conclusion, it is right to express admiration for the organisation displayed by the National Academy of Sciences of India. Perhaps one suggestion may be proffered. Readers would greatly appreciate guidance from page headings.

E. B. BaIley

1 Sympasium on the Age of the Saline Series of the Punjab, Proc. Nat. Acad. Sci. India, 14, Pt. 6, 1-xxxii, 205-334, 9 plates, 29 text-flgs. (1945). Price, including postage, Rs. 4/8 (India); Rs. 5 (foreign). - Second Symposium, Proc. Nat. Acad. Sci. India, 16, Pts. 2-4, 1-1, 29-257, 45 plates, 44 text-figs. (1947). Price, including postage, Rs. $12 / 8$ (India); Rs. 15 (foreign).

\section{SIR CHARLES SHERRINGTON AND DIPHTHERIA ANTITOXIN}

A $T$ a recent informal gathering of some men of A science an important matter of scientific interest was brought up by Dr. A. N. Drury, director of the Lister Institute, recording an incident in which Sir Charles Sherrington had played a part more than half a century ago.

The incident concerned the very first occasion on which diphtheria antitoxin was made in England. Dr. Drury exhibited one of the hooves, suitably mounted, of "Tommy", the first horse to be injected in England with diphtheria toxin with the object of obtaining diphtheria antitoxin for clinical use ; and he explained how the Brown Institution came to be associated with the British Institute of Preventive Medicine-as the Lister Institute was then calledwhich had accommodation for small animals only in the kitchen of the private residence in which it was housed. Dr. Drury described how "Tommy" was stabled at the Brown Institution, and how that, here, Dr. Armand Ruffer, then secretary of the British (now Lister) Institute, and Sir Charles Sherrington, who was at that time professor-superintendent of the Brown Institution, made those first injections and withdrew those samples of blood which yielded the first British-made diphtheria antitoxin. Listeners were also interested to learn that "Tommy's" performance as an antitoxin-producer would rank high even at the present day. Many other attendant circumstances of the incident and the time (August 1894 and the later months of that year) were reported by Dr. Drury, among which may be mentioned the lively interest of Sir Joseph Lister (as he then was); the sending of diphtheria antitoxin from Paris to be tried on patients in England pending the material from the horse "Tommy" and, no doubt, other horses immunized by Dr. Ruffer and Sir Charles Sherrington, becoming available; Pasteur's interest and concern that those attempting its preparation in England should benefit by the experience of those colleagues in France who had succeeded in preparing this entirely new type of medicament; and the clinical experience of English medical men who were privileged to use these early preparations. A letter from Dr. Roux of the Pasteur Institute, and others from practitioners who used the antitoxin, were read and exhibited. 
Dr. Drury's clear exposition of this historic event, and the unique character of the exhibits connected with it, aroused the greatest interest, and it was agreed that Sir Charles Sherrington's interest would be even greater. A letter was accordingly written and the following is an extract from his reply dated Novem. ber 15,1947 :

". . . Thank you for kindly writing. Yes, the story was just as you say; except that dear Ruffer's first name was Armand. Poor fellow, he was torpedoed and drowned by the Germans in the lst world war. $\mathrm{He}$ was brother-in-law to Bouchard of Paris, the leading French physician in his line.

"The story of the horse at 'the Brown' had a dramatic sequel which perhaps Dr. Drury has not heard; if he has, he will, I hope, forgive my telling it; it may interest you. Ruffer and I had been injecting the horse-our first horse-only a short time. We were badly in the dark as to the dosage to employ, and how quickly to repeat the increasing injections. We had from it a serum partly effective in guinea pigs. Then, on a Saturday evening, about 7 o'clock, came a bolt from the blue. A wire from my brother-in-law in Sussex. 'George has diphtheria. Can you come ?' George, a boy of 7 , was the only child. The house, an old Georgian house, 3 miles out of Lewes, set back in a combe under a chalk down. There was no train that night. I did not at first give thought to the horse, and, when I did, regretfully supposed it could not yet be ripe for use. However, I took a cab to find Ruffer. No telephone or taxi in those days-'93 or '94. Ruffer was dining out. I pursued him and got a word with him. He said 'By all means you can use the horse, but it is not yet ripe for trial'. Then by lantern-light at 'The Brown' I bled the horse into a 2-litre flask duly sterilized and plugged with sterile wool. I left the blood in ice for it to settle. After sterilizing smaller flasks, and pipettes and some needle-syringes I drove home, to return at midnight, and decant the serum, etc.

"By the Sunday morning train I reached Lewes. Dr. Fawssett of Lewes-he had a brother on the staff at Guy's-was waiting in a dog-cart at the station. I joined him carrying my awkward package of flasks, etc. He said nothing as I packed them in, but, when I had elimbed up beside him, he looked down and said, "You can do what you like with the boy. He will not be alive at tea time.' We drove out to the old house; a bright frosty morning. Tragedy was over the place, the servants scared and silent. The boy was very weak; breathing with difficulty; he did not seem to know me. Fawssett and I injected the serum. The syringes were small and we emptied them time and again. The Doctor left. I sat with the boy. Early in the afternoon the boy seemed to me clearly better. At 3 o'clock I sent a messenger to the Doctor to say so. Thence forward progress was uninterrupted. On Tuesday I returned to London, and sought out Ruffer. His reaction was that we must tell Lister about it. The great surgeon (not Lord Lister then) had visitors, some Continental surgeons, to dinner. 'You must tell my guests about it', he said, and insisted-so we told them in the drawing-room, at Park Crescent. The boy had a severe paralysis for a time. He grew to be $6 \mathrm{ft}$. and had a commission in the lst world war.

"If Drury has not heard of this sequel to the first horse at 'the Brown' he may like to hear it; please give him my best remembrances. . . . Thank you so much for writing. . . ."

\section{OBITUAR IES}

Prof. A. N. Whitehead, O.M., F.R.S.

ALFRED North Whitehead was born on February 15, 1861, the son of the Rev. Alfred Whitehead, at that time the headmaster of a private school in Ramsgate, and later vicar of St. Peter's, Isle of Thanet, and honorary canon of Canterbury. From Sherborne School he proceeded in 1880 to Trinity College, Cambridge, of which foundation he became a fellow in 1884 and lecturer in $\mathbf{1 8 8 5}$.

As a young man, he had a place apart among Cambridge dons by reason of his interest in the outlying and comparatively unknown branches of mathematics. In the nineteenth century, this category included non-Euclidean geometry and noncommutative algebras, such as matrices and symbolic logics; and on these subjects he published in 1898 a massive and very original volume, under the title "A Treatise on Universal Algebra, with Applications".

It is interesting to observe how Whitehead's prophetic instinct led him to take up subjects which were at the time neglected and unknown to most professional mathematicians, but which have since played a great part in the interpretation of Nature. Matrix theory first came into its kingdom in 1925, when Heisenberg, Born and Jordan showed that by its aid quantum theory could be constituted as a complete logical structure. The non-Euclidean geometry of spaces of constant curvature has found its chief application in the cosmological investigations of Eddington and others from 1930 onwards, though Euclidean space had been dethroned fifteen years earlier by Einstein's theory of general relativity. The "Universal Algebra" was acclaimed on all sides as a splendid work of learning and research, and the reputation based on it led to Whitehead's election as a fellow of the Royal Society in 1903.

Of the scholars of Trinity who sat at Whitehead's feet during the last decade of the nineteenth century, there was one who became a specially attached disciple and played a great part in his subsequent life and work. This was Bertrand Russell, who entered the College in 1890 and was elected a fellow in 1895. In 1900 he and Whitehead attended an International Philosophical Congress in Paris, at which they heard an account of the work of Giuseppe Peano, who in the years immediately preceding had invented a new ideography for use in symbolic logic. They realized that Peano's symbolism was vastly superior to anything that had been known previously, and resolved to devote themselves to its development, and in particular to try to settle by its means the vexed question of the foundations of mathematics.

The thesis which they now set out to prove was that mathematics is a part of logic; it is, as they said, the science concerned with the logical deduction of consequences from the general premises of all reasoning ; so that a separate "philosophy of mathematics' simply does not exist. This, of course, contradicts the Kantian doctrine that mathematical proofs depend on a priori forms of intuition. They soon succeeded in proving that the cardinal numbers 1,2 , $3, \ldots$ can be defined in terms of concepts which belong to pure logic, and which can be represented by Peano ideograms. From this first success they advanced to the investigations published in the three colossal volumes of "Principia Mathematica", which appeared during 1910-12 and contain altogether just under 2,000 pages. 